\title{
Pengaruh Pandemic Covid 19 terhadap Net Performing Financing Bank Pembiayaan Syariah di Indonesia
}

\author{
Maria Indriyani Hewe Tiwu, Yohana Febiani Angi
}

Fakultas Ekonomi dan Bisnis, Universitas Nusa Cendana

Email: indrianihewe@staf.undana.ac.id,yfangi@staf.undana.ac.id

\begin{tabular}{l}
\hline Article Info \\
\hline Article history: \\
Published: June 28, 2021 \\
Page: $96-104$ \\
\hline
\end{tabular}

Keyword:

NPF; Pandemic Covid 19;

BPR Syariah Indonesia,

\begin{abstract}
Penelitian ini bertujuan untuk menganalisis pengaruh pandemic covid 19 terhadap NPF BPR Syariah selama periode penelitian dari bulan Januari 2017 sampai dengan bulan Juuli 2019. Metode analisis yang digunakan adalah regresi erganda dengan pandemic covid 19 sebagai variabel dummy. Hasil dari penelitian ini menunjukan bahwa pandemic covid 19 tidak berpengaruh signifikan terhadap Net Performing Finance BPR syariah selama periode penelitian. BPR syariah menerapkan prinsip syariah yakni penyediaan dana atau tagihan yang dipersamakan dengan hasil dalam mudharabah, istishna, murabahah dan musyarakah, sehingga dampak dari pandemic covid 19 tidak berpengaruh signifikan terhadap NPF BPR syariah.
\end{abstract}

Kata Kunci : NPF; Pandemic Covid 19; BPR Syariah

This study aims to analyze the effect of the Covid 19 pandemic on NPF BPR Sharia during the study period from January 2017 to July 2019. The analytical method used is multiple regression with the COVID-19 pandemic as a dummy variable. The results of this study indicate that the Covid 19 pandemic has no significant effect on the Net Performing Finance of Islamic BPRs during the study period. Islamic BPRs apply sharia principles, namely the provision of funds or bills that are equalized to the results in mudharabah, istishna, murabahah and musyarakah, so that the impact of the Covid pandemic does not have a significant effect on the NPF of Islamic BPRs

Keywords: NPF; Pandemic Covid 19; BPR Syariah

\section{Pendahuluan}

Bank mempunyai peranan yang strategis dalam perekonomian suatu Negara.
Sebagai lembaga intermediasi, bank berperan dalam memobilisasi dana masyarakat yang digunakan untuk

\section{Editorial Office:}

Prodi Ilmu Ekonomi Fakultas Ekonomi dan Bisnis Islam, UIN Sunan Ampel Surabaya

Jl. Ahmad Yani 117 Surabaya, Jawa Timur 60237, Indonesia.

Email: oje@uinsby.ac.id 
membiayai kegiatan investasi serta memberikan fasilitas pelayanan dalam lalu lintas pembayaran. Selain menjalankan kedua perencanaan tersebut, bank juga berfungsi sebagai perantara dalam mentransmisikan kebijakann moneter yang dilakukan oleh Bank Indonesia untuk menjaga kestabilan sektor moneter, oleh karena itu kinerja dari sektor perbankan sangat diperhitungkan dalam perekonomian. Perbankan di Indonesia pada umumnya dibagi menjadi dua yakni bank konvensional dan bank syariah yang melakukan kegiatan atau aktivitas ekonomi perbankan didasarkan pada prinsip syariah.

Pengembangan sistem perbankan syariah di Indonesia dilakukan dalam kerangka dual-banking system atau sistem perbankan ganda dalam kerangka Arsitektur Perbankan Indonesia (API), untuk menghadirkan alternatif jasa perbankan yang semakin lengkap kepada masyarakat Indonesia. Secara bersama-sama, sistem perbankan syariah dan perbankan konvensional secara sinergis mendukung mobilisasi dana masyarakat secara lebih luas untuk meningkatkan kemampuan pembiayaan bagi sektor-sektor perekonomian nasional (www.ojk.com)

Dalam perbankan syariah karakteristik sistem perbankannya beroperasi berdasarkan prinsip bagi hasil memberikan alternatif sistem perbankan yang saling menguntungkan bagi masyarakat dan bank, serta menonjolkan aspek keadilan dalam bertransaksi, investasi yang beretika, mengedepankan nilai-nilai kebersamaan dan persaudaraan dalam berproduksi, dan menghindari kegiatan spekulatif dalam bertransaksi keuangan. Dengan menyediakan beragam produk serta layanan jasa perbankan yang beragam dengan skema keuangan yang lebih bervariatif, perbankan syariah menjadi alternatif sistem perbankan yang kredibel dan dapat dinimati oleh seluruh golongan masyarakat Indonesia tanpa terkecuali.

Salah satu struktur perbankan syariah adalah Bank Pembiayaan Syariah
(BPR syariah) yang dalam kegiatannya menyalurkan dana kepada masyarakat namun tidak memberikan jasa dalam lalu lintas pembayarannya. Namun pada kondisi pandemic covid 19 yang telah memperngaruhi perekonomian Negaranegara di dunia termasuk Negara Indonesia.

Perekonomian Indonesia mengalami dampak buruk dari pandemic covid 19, dan untuk mengatasi pandemic tersebut pemerintah menerapkan protokol kesehatan yakni Pembatasan Sosial Berskala Besar (PSBB) dan social distancing yang diharapkan dapat mengatasi pandemic covid 19. Namun dampak dari pandemic ini terus menular dan memberikan pengaruh terhadap Indonesia baik dalam sektor riil dan sektor moneter, akibatnya perekonomian Indonesia mengalami perlambatan bahkan pertumbuhan ekonomi mencapai $-5.32 \%$ pada kuartal ke 2 (sumber BPS.go.id).

Industri pariwisata, pertambangan, konstruksi, otomotif, transportasi, UMKM mengalami penurunan akibat covid 19. Sektor keuangan khususnya perbankan juga mengalami ancaman ketidakmampuan dunia usaha untuk membayar pinjaman. Pada tahun 2019 dan 2020 penyaluran kredit melalui Bank Pembiayaan Rakyat mengalami penurunan selama bulan Maret 2020 hingga Mei 2020 namun pada bulan Juli 2020 mengalami peningkatan dalam penyaluran kredit seperti pada grafik 1 berikut ini

Grafik 1.

Perkembangan penyaluran Kredit BPR syariah

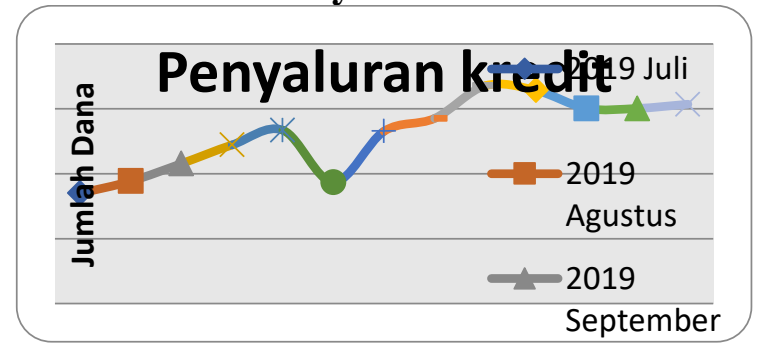

Sumber: (SPI, Diolah)

Implikasi dari tidak bekerjanya para pekerja formal ataupun pekerja informal adalah kehilangan pendapatan dan 
keuntungan, sehingga berdampak pada sektor usaha atau UMKM yang dijalankan oleh para pengusaha. Hal ini akan mendorong terjadinya ketidakmampuan debitur atau peminjam untuk mengembalikan dana yang dipinjam. Berikut adalah grafik yang menunjukan perkembangan kredit macet selama bulan Juli 2019 sampai dengan bulan Juli 2020, dimana pergerakan dari grafik kredit macet tersebut mengalami peningkatan.

\section{Grafik 2}

Perkembangan Penyaluran Kredit BPR Syariah

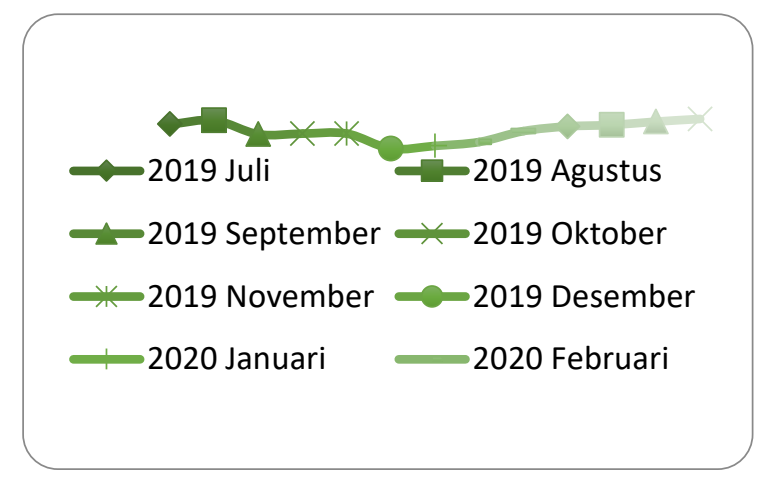

Sumber: (SPI, Diolah)

Perkembangan kredit macet yang terus meningkat selama periode tersebut tentu saja memberi pengaruh terhadap rasio risiko usaha bank yang menunjukkan besarnya risiko kredit bermasalah (NPF) yang ada pada BPR syariah.

\section{Grafik 3 \\ Net Performing Financing BPR Syariah}

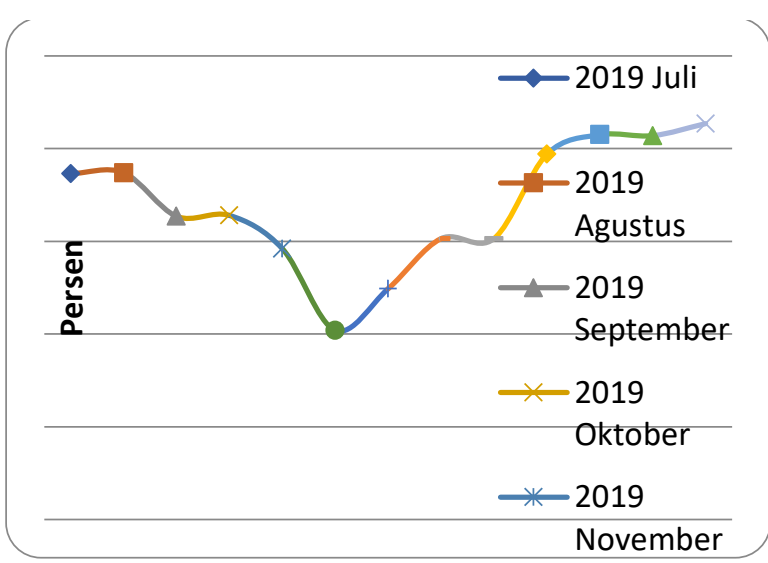

Sumber: (SPI, Diolah)
Pada grafik 3, NPF pada tahun 2020 dimana masa pandemic covid 19 masih berlangsung dan terus meningkat, menyebabkan penurunan kinerja BPR syariah dan menjadi tidak efisien.

Hal ini dapat dibuktikan dengan ROA dari BPR syariah pada grafik 4:

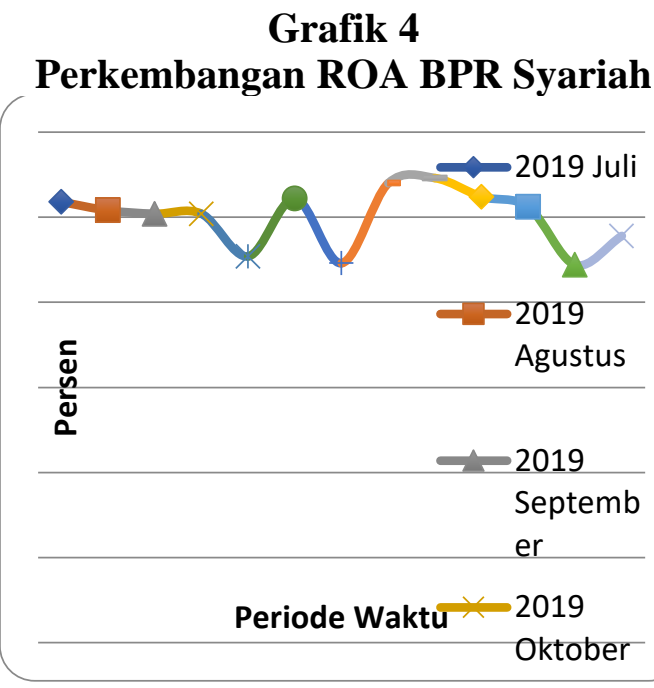

Sumber: (SPI, Diolah)

Pada grafik 4 pergerakan ROA Januari 2020 sampai dengan Februari 2020 mengalami peningkatan tetapi pada bulan Maret sampai dengan bulan Juni mengalami penurunan namun mulai meningkat pada bulan Juli.

Pemerintah Indonesia melalui Bank Indonesia telah melakukan berbagai upaya kebijakan untuk merestrukturisasi kredit atau pembiayaan, salah satu caranya adalah kebijakan menurunkan suku bunga BI7DRR menjadi $4 \%$ serta melakukan koordinasi dengan kementerian keuangan dan Otoritas Jasa Keuangan (OJK).

Berdasarkan uraian di atas maka rumusan masalah yang ingin dianalisis adalah apakah pandemic covid 19 dan suku bunga BI7DRR berpengaruh terhadap meningkatnya rasio NPF BPR syariah. 


\section{Kajian Pustaka}

\section{BPR Syariah}

Menurut OJK Bank Pembiayaan

Rakyat syariah adalah Bank yang melaksanakan kegiatan usaha secara konvensional atau berdasarkan prinsip syariah, yang dalam kegiatannya tidak meberikan jasa dalam lalu lintas pembayaran, dimana kegiatan BPR jauh lebih sempit jika dibandingkan dalam kegiatan bank umum karena BPR dilarang menerima giro, kegiatan valas dan perasuransian.

Seperti lembaga keuangan lainnya, BPR syariah juga melakukan kegiatan yang berkaitan dengan menghimpun dana dan menyalurkan kredit. Hal ini tercantum pada undang-undang perbankan No.10 1998. Namun, tidak sperti Bank Umum syariah ataupun unit usaha syariah, ada beberapa kegiatan yang dilarang dilakukan BPRS menurut undang-undang No.17 pasal 14 tahun 1992

a) Kegiatan BPR syariah yang diperbolehkan

a) Menghimpun dana dari masyarakat dalam bentuk simpanan berupa deposito berjangka, tabungan dan atau bentuk lainnya yang dipersamakan dengan itu.

b) Memberikan kredit

c) Menyediakan pembiayaan dan penempatan dana berdasarkan prinsip syariah sesuai dengan ketentuan yang ditetapkan oleh Bank Indonesia

d) Menempatkan dananya dalam bentuk sertifikat Bank
Indonesia, deposito berjangka, sertifikat deposito, dan atau tabungan pada bank lain

b) Kegiatan BPR syariah yang dilarang

a) Menerima simpanan dalam bentuk giro dan ikut serta dalam lalu lintas pembayaran

b) Melakukan kegiatan usaha dalam bentuk valuta asing

c) Melakukan penyertaan modal

d) Melakukan usaha perasuransian

e) Melakukan usaha lain di luar kegiatan usaha sebagaimana disebutkan pada kegiatan usaha yang boleh dilakukan oleh BPR syariah.

\section{Net Performing Financing}

Non Performing Financing (NPF) merupakan indicator pembiayaan bermasalah yang perlu diperhatikan karena sifatnya yang fluktuatif dan tidak pasti sehingga penting untuk diamati dengan perhatian khusus. NPF merupakan salah satu instrument penilaian kinerja sebuah bank syariah yang menjadi intrepretasi penilaian pada aktifa produktif,khususnya dalam penilaian pembiayaan bermasalah. Pembiayaan adalah penyediaan dana atau tagihan yang dipersamakan dengan hasil dalam mudharabah dan musyarakah.

Perhitungan NPF sangat dibutuhkkan oleh bank atau pihak investor karena dapat dijadikan sebagai cerminan resiko pembayaran. Setiap bank memang harus selalu menanggung resiko pembiayaan. Namun semakin tinggi rasio NPF maka semakin tinggi resiko pembiayaan yang harus ditanggung, 
akibatnya pihak bank harus bisa menyediakan cadangan dana yang lebih besar untuk menutupi resiko tersebut.

Besar kecilnya NPF pada sebuah bank dapat dipengaruhi oleh faktor internal dan faktor eksternal. Faktor internal meiputi berbagai permasalahan yang ada dalam tubuh bank itu sendiri terutama faktor manejerial dan operasional bank. Sedangkan faktor eksternal adalah faktor yang tidak dapat dikendalikan oleh bank, dan mungkin saja tidak berhubungan dengan perekonomian. Misalnya bencana alam, perubahan teknologi, pandemic dan lain sebagainya.

Faktor eksternal seperti musibah yang berskala nasional dapat berpengaruh terhadap Rasio NPL yang menunjukan kinerja perbankan. Pandemic covid 19 merupakan salah satu faktor eksternal.

Pandemic covid 19 adalah suatu penyakit yang disebabkan oleh virus SARS $\mathrm{CoV}-2$ dan memiliki gejala yang mirip dengan flu biasa, yang dapat berlanjut pada sakit parah dan radang paru (Pneumonia),sehingga menyebabkan kesulitan bernafas.Virus Corona menyebabkan penyakit flu biasa sampai penyakit yang lebih parah seperti Sindrom Pernafasan Timur Tengah (MERS-CoV) dan Sindrom Pernafasan Akut Parah (SARS$\mathrm{CoV}$ ). Virus ini menular dengan cepat dan telah menyebar ke beberapa negara, termasuk Indonesia.

Organisasi Kesehatan Dunia (WHO), sebagai sumber acuan dunia dalam menghadapi Covid-19, telah merilis beberapa langkah-langkah perlindungan dasar individu dalam menghadapi Pandemi ini. Beberapa diantaranya yaitu menjaga kebersihan tangan melalui rajin cuci tangan dengan sabun dan air mengalir atau dengan cairan berbasis alkohol, menjaga jarak sosial (Social distancing) dengan cara menjaga jarak setidaknya 1 meter dengan orang lain atau siapa saja yang batuk atau bersin, hindari menyentuh mata, hidung dan mulut, karena ketiganya merupakan jalan masuknya virus ke dalam tubuh, menjaga kebersihan pernafasan dengan cara menutup mulut dan hidung dengan tisu atau dengan siku pada saat batuk dan bersin, jika mengalami demam, batuk dan kesulitan bernafas, cari perawatan medis sesegera mungkin, serta tetap mencari informasi dan mengikuti saran yang diberikan oleh penyedia layanan kesehatan setempat.

Covid-19 berdampak besar hampir di semua aspek kehidupan termasuk ekonomi. Untuk mengatasi badai ini, berbagai Negara berjuang keras untuk mengatasi dampak wabah Covid-19 selain koordinasi, tindakan penting untuk membatasi penyebaran pandemi Covid-19 dan mengatasi konsekuensi sosial-ekonomi adalah langkah-langkah seperti: penting memperhatikan rantai nilai produksi dan distribusi untuk memastikan kepastian pasokan yang diperlukan; memastikan bahwa pendapatan dan peluang kerja tidak terpengaruh oleh pandemic. Dukungan pada perusahaan terdampak khususnya Usaha Kecil dan Menengah (UKM), koperasi, dan usaha sektor informal terjaminnya supply dan ketersediaan stok pangan. Kita harus merespon bersama untuk memperlambat penularan, memperkuat ketahanan sistem layanan kesehatan agar wabah Covid-19 dapat diatasi dengan cepat. 


\section{Metode Penelitian}

\section{Pendekatan Penelitian}

Pendekatan yang digunakan dalam penelitian ini adalah pendekatan statistik inferensi.

\section{Jenis dan Sumber Data}

Jenis data dari penelitian ini adalah data kuantitatif dengan menggunakan sumber data sekunder berbentuk time series 43 bulan dari Januari 2107 sampai dengan Juli 2020

\section{Variabel dan Definisi Operasional}

Variabel dependen adalah variabel NPF, sedangkan variabel independen adalah variabel suku bunga BI7DRR dan dummy pandemic covid 19 dimana variabel suku bunga BI7DRR menjadi variabel control terhadap dummy pandemic covid 19. Definisi operasional dari variabel ekonomim dalam persamaan regresi berganda adalah sebagai berikut:

NPF (Y)

Perbandingan antara kredit bermasalah dengan jumlah kredit yang disalurkan kepada masyarakat secara keseluruhan (\%).

Suku Bunga BI7DDR(X1)

Kebijakan nilai suku bunga yang ditetapkan oleh Bank Indonesia yang bersangkutan dengan kebijakan moneter $(\%)$

Pandemic Covid 19 (X2 Dummy Variabel)

Keadaan sebelum dan selama terjadi pandemic Covid 19

\section{Teknik Analisis Data}

Metode analisis yang digunakan dalam penelitian ini adalah analisis regresi berganda dengan model sebagai berikut :

$$
Y_{t}=\beta_{0}+\beta_{1} X_{1 t}+\beta_{2} X_{2 t}+\beta_{3} D X_{3 t}+\varepsilon_{t}
$$

dalam analisi regresi berganda dilanjutkan dengan melakukan uji berikut:

Asumsi klasik agar hasil estimasi dapat bersifat BLUE (Best, Linear, Unbias Estimator) yang meliputi uji multikolinearitas menggunakan metode varience inflation factors, uji heteroskedastisitas menggunakan metode uji white dan uji autokorelasi menggunakan metode uji Durbin Watson.

Uji hipotesis meliputi

Uji Parsial

Variabel suku bunga BI7DRR

Ho: $\beta_{2}<0$ : variabel suku bunga BI7DRR tidak berpengaruh signifikan terhadap NPF

Ha: $\beta_{2}>0$ : variabel suku bunga BI7DRR berpengaruh signifikan terhadap NPF

Variabel $\mathrm{X}_{3}$ (dummy pandemic Covid 19

Ho: $\beta_{3}<0$ : variabel pandemic Covid 19 tidak berpengaruh signifikan terhadap NPF

Ha: $\beta_{3}>0$ : variabel pandemic Covid 19 berpengaruh signifikan terhadap NPF Uji Simultan

Ho: $\beta_{1} ; \beta_{2} ; \beta_{3}<0$ : variabel inflasi, suku bunga BI7DRR, dan pandemic covid 19 tidak berpengaruh signifikan terhadap NPF

Ha: $\beta_{1}>0: \beta_{1} ; \beta_{2} ; \beta_{3}<0$ : variabel inflasi, suku bunga BI7DRR, dan pandemic covid 19 berpengaruh signifikan terhadap NPF

Uji koefisien determinasi dimaksudkan untuk menganalisis bagaimana pengaruh variabel $\mathrm{X} 1, \mathrm{X} 2$ dan $\mathrm{X} 3$ dalam model persamaan regresi berganda terhadap variasi perubahan variabel Y.

\section{Hasil dan Pembahasan}

\section{Hasil Penelitian}

Berdasarkan hasil pengolahan data NPF, Suku Bunga BI7DRR dan dummy covid 19 diperoleh hasil estimasi sebagai berikut: 
Tabel 1

Hasil Regresi Berganda

\begin{tabular}{|c|c|}
\hline Variabel & Koefisien \\
\hline $\begin{array}{c}\text { X1 (Suku Bunga } \\
\text { BI7DRR }\end{array}$ & 0.1303 \\
\hline $\begin{array}{c}\text { X2 Dummy } \\
\text { Pandemic Covid } \\
19\end{array}$ & 1.321 \\
\hline
\end{tabular}

Sumber: data diolah,2020

Pada tabel 1, diperoleh persamaan regresi linear berganda sebagai berikut: $\mathrm{Y}=-12.124+0.1303 \mathrm{X} 1+1.321 \mathrm{X} 2 \mathrm{DPC}+\varepsilon$

1) Hasil Uji Asumsi Klasik

a) Uji Heteroskedastisitas

Tabel 2

Hasil Uji Heteroskedastisitas Heteroskedasticity Test: BreuschPagan-Godefrey

\begin{tabular}{|c|c|c|}
\hline Obs $*$ R-Square & $\begin{array}{c}\boldsymbol{t} \text { - } \\
\text { statisti } \\
\boldsymbol{c} \\
\text { proba } \\
\text { bility }\end{array}$ & Alfa \\
\hline Prob.Chi-Square & 0.2443 & 0.05 \\
\hline
\end{tabular}

Sumber: data diolah,2020

(1) Hipotesis test

Ho $: \sigma^{2}=\sigma^{2}$ (Varians adalah sama atau tidak terjadi heteroskedastisitas) $\mathrm{Ha}: \sigma^{2} \neq \sigma^{2}$ (Varians adalah tidak sama atau terjadi heteroskedastisitas)

(2) Test criteria

Tidak menolak Ho : Prob. Chi-square obs $* R$ - square $>(0,05)$

Menolak Ho : Prob. Chi-square $o b s * R$-square $<\quad(0,05)$

(3) Conclusion

Berdasarkan tabel 2, nilai Prob. ChiSquare $o b s * R$ - square sebesaar $0.2443>\alpha(0,05)$, maka dapat diambil kesimpulan bahwa hasil output dari estimator yang digunakan bebas dari penyakit heteroskedastisitas.

b) Uji Autokorelasi
Hasil dari uji autokorelasi dengan menggunakan metode Uji BreuschGodfrey Serial Corelation LM Test

Tabel 2

Hasil Uji Autocorelation

Breusch- Godefrey Serial Corelation LM Test

\begin{tabular}{|c|c|c|}
\hline Obs $* \boldsymbol{R}$-Square & $\begin{array}{c}\boldsymbol{t} \text { - } \\
\text { statistic } \\
\text { probabi } \\
\text { lity }\end{array}$ & Alfa \\
\hline Prob.Chi-Square & 0.5426 & 0.05 \\
\hline \multicolumn{2}{|l|}{ Sumber: }
\end{tabular}

(1) Hipotesis test

Ho : $\sigma^{2}=\sigma^{2} \quad$ ( Tidak terjadi Autocorelation)

Ha : $\sigma^{2} \neq \sigma^{2}$ (Terjadi Autocorelation)

(2) Test criteria

Tidak menolak Ho : Prob. Chi-square $o b s * R-\quad$ square $>(0,05)$

Menolak Ho : Prob. Chi-square obs*R-square $<(0,05)$

(3) Conclusion

Berdasarkan tabel 3, nilai Prob. ChiSquare obs*R- square sebesaar $0.5426>\alpha(0,05)$, maka dapat diambil kesimpulan bahwa hasil output dari estimator yang digunakan bebas dari penyakit Autokorelasi.

2) Hasil Uji statistik.

a) Uji Parsial(uji t)

Tabel 3

Hasil Uji Parsial

\begin{tabular}{|l|c|c|}
\hline Variable & \multicolumn{1}{c|}{$\begin{array}{c}\boldsymbol{t} \text { - } \\
\text { statisti } \\
\boldsymbol{c}\end{array}$} & $\begin{array}{c}\text { proba } \\
\text { bility } \\
\text { t- } \\
\text { statisti } \\
\boldsymbol{c}\end{array}$ \\
\hline X1 (BI7DRR) & 1.4971 & 0.142 \\
\hline $\begin{array}{l}\text { X2 (Covid } 19 \\
\text { Dummy) }\end{array}$ & 0.0986 & 0.92 \\
\hline
\end{tabular}

Sumber: data diolah,2020

(1) Variabel BI7DRR

Dari tabel 3 diperoleh nilai t hitung sebesar 1.4971 dengan nilai $t$ tabel dengan taraf 
signifikansi yang digunakan 5\% maka diperoleh nilai sebesar 1.684.. Berdasarkan criteria pengujian, jika nilai t hitung lebih kecil $(1.4971)$ < dari nilai $\mathrm{t}$ tabel (1.684) maka variabel BI7DRR tidak berpengaruh signifikan terhadap variabel NPF. Kesimpulannya adalah variabel BI7DRR tidak mempunyai pengaruh yang signifikan terhadap variabel NPF BPR syariah selama periode penelitian.

\section{(2) Covid 19 Dummy}

Dari tabel 3 diperoleh nilai $\mathrm{t}$ hitung sebesar 0.0986 dengan nilai $\mathrm{t}$ tabel dengan taraf signifikansi yang digunakan 5\% maka diperoleh nilai sebesar 1.684.. Berdasarkan criteria pengujian, jika nilai t hitung lebih kecil (0.0986) < dari nilai t tabel (1.684) maka variabel covid 19 dummy tidak berpengaruh signifikan terhadap variabel NPF. Kesimpulannya adalah variabel covid 19 dummy tidak mempunyai pengaruh yang signifikan terhadap variabel NPF BPR syariah selama periode penelitian

\section{b) Uji Simultan}

Tabel 4

Simultan Estimation Ouput

\begin{tabular}{|c|c|c|}
\hline Variable & $\begin{array}{c}t- \\
\text { statisti } \\
c\end{array}$ & $\begin{array}{c}\text { probabili } \\
\text { ty } t- \\
\text { statistic }\end{array}$ \\
\hline X1 (BI7DRR), & & \\
\hline $\begin{array}{l}\text { X2(Covid } \\
\text { dummy) }\end{array}$ & 1.2416 & 0.2997 \\
\hline
\end{tabular}

Sumber: data diolah,2020

Dari tabel 4 dapat diperoleh nilai $\mathrm{f}$ hitung sebesar 1.241 dengan nilai $t$ tabel sebesar 3.23. Berdasarkan kriteria pengujian jika nilai $\mathrm{f}$ hitung lebih besar $(1.241)>\mathrm{t}$ tabel (3.23) artinya variabel X1 (Suku bunga BI7DRR) dan X2 (dummy pandemic covid 19) tidak berpengaruh signifikan secara simultan terhadap variabel NPF. Jika diuji dengan menggunakan nilai probabilitas $\mathrm{f}$ hitung sebesar 0.2997 > taraf signifikan 0,05 artinya variabel X1 (Suku bunga BI7DRR) dan X2 (dummy pandemic covid 19) tidak berpengaruh signifikan secara simultan terhadap NPF. Kesimpulan dari hasil pengujian ini dengan menggunakan nilai $f$ hitung dan nilai probabilitas f hitung maka dapat disimpulkan bahwa variabel X1 (Suku bunga BI7DRR) dan X2 (dummy pandemic covid 19) tidak berpengaruh signifikan secara simultan terhadap rasio NPF BPR syariah selama periode penelitian

\section{Pembahasan}

NPF merupakan salah satu instrument penilaian kinerja sebuah bank syariah yang menjadi intrepretasi penilaian pada aktifa produktif,khususnya dalam penilaian pembiayaan bermasalah.

Secara teori ukuran NPF pada sebuah bank dapat dipengaruhi oleh faktor internal dan faktor eksternal. Faktor internal meliputi berbagai permasalahan yang ada dalam bank itu sendiri terutama faktor manejerial dan operasional bank. Sedangkan faktor eksternal adalah faktor yang tidak dapat dikendalikan oleh bank, dan mungkin saja tidak berhubungan dengan perekonomian. Misalnya bencana alam, perubahan teknologi, pandemic dan lain sebagainya.

Faktor eksternal seperti musibah yang berskala nasional dapat berpengaruh terhadap Rasio NPL yang menunjukan kinerja perbankan. Pandemic covid 19 merupakan salah satu faktor eksternal. Berdasarkan penelitian yang dilakukan oleh Maria Indri dengan judul Pengaruh Pandemiv Covid 19 Terhadap NPL BPR di Indonesia, pandemic covid 19 berpengaruh siginifikan terhadap NPL. Tapi dari hasil penelitian ditemukan hal yang berbeda dengan NPF BPR syariah, dimana dari hasil penelitian menunjukan bahwa pandemic covid 19 tidak berpengaruh signifikan terhadap NPF BPR syariah selama periode penelitian.

Pandemic covid 19 tidak berpengaruh secara signifikan terhadap NPF bisa disebabkan oleh faktor-faktor internal, salah satunya adalah pembiayaan atau penyedian dana yang didasarkan pada yang dipersamakan dengan hasil dalam mudharabah, istishna, murabahah dan 
musyarakah. Pembiayaan murabahah dimana perjanjian antara bank dan nasabah, bank menyediakan modal atau pembelian bahan baku, kemudian dibayar nasabah sesuai harga jual bank (dimana harga beli bank plus margin keuntungan) sedangkan pembiayaan musyarakah adalah penggabungan modal antara dana pengusaha dan bank kemudian keuntungan dibagi berdasarkan kesepakatan awal. Pembiayaan Istishna merupakan pembiayaan dengan prinsip jual beli, bank membelikan barang lalu nasabah mengikuti mekanisme pembayaran atau pengembalian disesuaikan dengan kemampuan atau keuangan nasabah.

\section{Kesimpulan}

Pandemi covid 19 merupakan kejadian luar biasa yang menyebabkan perekonomian di seluruh dunia termasuk Indonesia. Namun berdasarkan hasil penelitian dampak dari pandemic covid 19 tidak berpengaruh signifikan terhadap NPF BPR syariah.

Hal tersebut dikarenakan faktor internal yang cukup kuat pada BPR syariah dimana BPR Syariah menerapkan prinsip syariah yakni penyediaan dana atau tagihan yang dipersamakan dengan hasil dalam mudharabah, istishna, murabahah dan musyarakah.

\section{Daftar Pustaka}

Agus,Gede dan Ni Nyoman Yuliarni.2013."Faktor-faktor Yang Mempengaruhi Penyaluran Kredit BPR Di Provinsi Bali'E-Jurnal Ekonomi Pembangunan. Vol.2, No.6. Juni2013. Universitas Udayana. Bali

Barus,Caroline, dan Erick. 2016. "Analisis Faktor-Faktor Yang Mempengaruhi Non Performing Loan Pada Bank Umum di Indonesia.'Jurnal Wira Ekonomi
Mikroskil Volume 6, Nomor 02, Oktober 2016. STIE Mikrosil, Medan.

BPS.go.id

Bank Indonesia.go.id

Gujarati,Damodar.2011."Dasar-dasar Ekonometrika". Buku 1, Edisi 5. Jakarta: Salemba Empat

Hasan, Iqbal. 2016. " Pokok-pokok Materi Statistik 2 (Statistik Inferensi)”. Jakarta: Bumi Aksara

"Statistik Perbankan Indonesia".web.OJK.go.id

Pratamawati,Putri.2018."Analisis Faktorfaktor yang Mempengaruhi Non Performing Loan Pada Bank Umum BUMN Tahun 2012-2016”.Skripsi. Universitas Negeri Yogyakarta.

Putro.Sukirno.2017."'Faktor-faktor Yang Mempengaruhi Penyaluran Kredit Pada Bank Perkreditan Rakyat (BPR) Di Provinsi Riau Tahun 2006-2015"Jurnal JOM Fekon, Vol.4 No.1. Februari 2017.Universitas Riau, Pekanbaru.

Tayono, dkk. "Analisis hukum Islam Tentang Pelaksanaan Akad Murabahah di BPR Syariah". Mimbar Keadilan. Vol 12. Nomor 2.2016

Tiwu,Maria Indri. "Pengaruh Pandemic Covid 19 Terhadap NPL Bank Perkreditan Rakyat Di Indonesia"2020. urnal Akuntansi: Transparansi dan Akuntabilitas, Oktober 2020, Vol.8,No.2, Hal.79-87. https://doi.org/10.35508/jak.v8i2.2869

Umardani, Dwi “ Analisis Perbandingan Kinerja Keuangan Bank Syariah dan Bank Konvensional di Indonesia" Jurnal Manajemen dan Pemasaran Jasa. Vol.9 No 1.2016

Winarno,Wahyu.2015."Analisis Ekonometrika dan Statistikadengan Eviews”. Yogyakarta: UPP STIM YKPN 